\begin{tabular}{|c|l|}
\hline Title & $\begin{array}{l}\text { Direct Synthesis of Phenol from Benzene over Platinum-loaded Tungsten(VI) Oxide Photocatalysts with Water and } \\
\text { Molecular Oxygen }\end{array}$ \\
\hline Author(s) & Tomita, Osamu; A be, Ryu; Ohtani, Bunsho \\
\hline Citation & $\begin{array}{l}\text { Chemistry Letters, 40(12), 1405-1407 } \\
\text { https://doi.org/10.1246/1.2011.1405 }\end{array}$ \\
\hline Issue Date & 2011-12 \\
\hline Doc URL & http://hdl.handle.net/2115/50779 \\
\hline Type & article(author version) \\
\hline File Information & CL40-12_1405-1407.pdf \\
\hline
\end{tabular}

Instructions for use 


\title{
Direct Synthesis of Phenol from Benzene over Platinum-loaded Tungsten(VI) Oxide Photocatalysts with Water and Molecular Oxygen
}

\author{
Osamu Tomita, ${ }^{1}$ Ryu Abe, ${ }^{* 1,2}$ and Bunsho Ohtani ${ }^{1,2}$ \\ ${ }^{1}$ Graduate School of Environmental Science, Hokkaido University, North10, West5, Kita-ku, Sapporo 060-0810 \\ ${ }^{2}$ Catalysis Research Center, Hokkaido University, North21, West10, Kita-ku, Sapporo 001-0021
}

(Received $<$ Month $>\langle$ Date $\rangle,\langle$ Year $>$; CL-<No>; E-mail: ryu-abe@ @at.hokudai.ac.jp)

Tungsten(VI) oxide loaded with nanoparticulate platinum $\left(\mathrm{Pt} / \mathrm{WO}_{3}\right)$ was demonstrated for the first time to exhibit photocatalytic activity for direct synthesis of phenol from benzene using water and molecular oxygen as reactants under ultraviolet or visible light irradiation; the selectivity for phenol (e.g., $74 \%$ at $69 \%$ of benzene conversion) on $\mathrm{Pt} / \mathrm{WO}_{3}$ photocatalysts was much higher than those on platinumloaded titanium(IV) oxide $\left(\mathrm{Pt} / \mathrm{TiO}_{2}\right)$ photocatalysts.

Hydroxylated aromatic compounds are the most important raw materials in chemical industry. For example, phenol is the major source of phenol resins, which are utilized in many commodities throughout the world. However, its industrial production still requires multistep reaction processes, namely cumene method, which consumes considerably large energy and yields a by-product, acetone. ${ }^{1}$ Direct synthesis of phenol from benzene in a one-step reaction, especially using environmentally benign oxidants such as molecular oxygen $\left(\mathrm{O}_{2}\right)$ or water, is highly desirable, and thus have been extensively studied..$^{2-4}$ However there have been few catalytic process that enables high benzene conversion with high phenol selectivity by using such environmentally benign oxidants $\left(\mathrm{O}_{2}\right.$ and/or water $)$. Photocatalysis on semiconductor materials may be one of the candidates for such clean and direct synthesis of phenol from benzene. Although several research groups have reported direct synthesis of phenol from benzene using titanium(IV) oxide $\left(\mathrm{TiO}_{2}\right)$ photocatalysts suspended in a water-benzene mixture in the presence of molecular $\mathrm{O}_{2},{ }^{5-10}$ the selectivity for phenol was generally low mainly due to the occurrence of subsequent peroxidation on photocatalyst. Yoshida et al. have demonstrated that the selectivity for phenol can be significantly improved by applying deaerated condition, i.e., the absence of $\mathrm{O}_{2}$, to Pt-loaded $\mathrm{TiO}_{2}$ photocatalyst system, however the efficiency was not so high possibly due to the lower capability of water (or proton) to capture the photoexcited electrons compared to $\mathrm{O}_{2}{ }^{11}$

In the present study, we report highly selective phenol production (ca. $74 \%$ at $69 \%$ of benzene conversion) on a Ptloaded tungsten(VI) oxide $\left(\mathrm{Pt} / \mathrm{WO}_{3}\right)$, which was recently developed as a highly efficient visible-light-responsive photocatalyst, $^{12}$ in an aqueous solution containing benzene and $\mathrm{O}_{2}$ under the irradiation of ultraviolet or visible light irradiation. The $\mathrm{Pt} / \mathrm{WO}_{3}$ photocatalysts showed much higher selectivity for phenol production than platinized (or bare) $\mathrm{TiO}_{2}$ photocatalysts. The different reactivity between $\mathrm{WO}_{3}$ and $\mathrm{TiO}_{2}$ photocatalysts toward benzene oxidation is discussed.
Commercially available $\mathrm{WO}_{3}$ powders such as $\mathrm{WO}_{3}-\mathrm{K}$ (Kojundo Chemical Laboratory, monoclinic, $2.2 \mathrm{~m}^{2} \cdot \mathrm{g}^{-1}$ ), $\mathrm{WO}_{3}-\mathrm{Y}$ (Yamanaka Chemical Industries, monoclinic, 2.2 $\mathrm{m}^{2} \cdot \mathrm{g}^{-1}$ ), and $\mathrm{WO}_{3} \mathrm{~S}$ (Soekawa Chemicals, monoclinic, 1.6 $\mathrm{m}^{2} \cdot \mathrm{g}^{-1}$ ) were used. Since the $\mathrm{WO}_{3}-\mathrm{K}$ sample consists of mixture of fine and large aggregated particles, fine particulate $\mathrm{WO}_{3}$ with a particle size of $50-200 \mathrm{~nm}$ was separated from $\mathrm{WO}_{3}-\mathrm{K}$ by the method reported previously, ${ }^{12}$ which will be denoted as $\mathrm{WO}_{3}-\mathrm{K}\left(10 \mathrm{~m}^{2} \cdot \mathrm{g}^{-1}\right)$ hereafter. $\mathrm{TiO}_{2}$ powders such as $\mathrm{TiO}_{2}-\mathrm{P} 25$ (Degussa (Evonik) P 25, $59 \mathrm{~m}^{2} \cdot \mathrm{g}^{-1}$ ), $\mathrm{TiO}_{2}-\mathrm{M}$ (Merck, anatase, $11 \mathrm{~m}^{2} \cdot \mathrm{g}^{-1}$ ), and $\mathrm{TiO}_{2}-\mathrm{J}$ (JRC-TIO-8 donated from the Catalysis Society of Japan, anatase, $338 \mathrm{~m}^{2} \cdot \mathrm{g}^{-1}$ ) were also used for comparison. The modification of photocatalysts with nanoparticulate $\mathrm{Pt}$ metal cocatalysts $(0.1 \mathrm{wt} \%)$ was accomplished by photodeposition from hexachloroplatinic acid $\left(\mathrm{H}_{2} \mathrm{PtCl}_{6} \cdot 6 \mathrm{H}_{2} \mathrm{O}\right)$ according to the method reported previously, which affords a highly uniform dispersion of platinum particles (average size, $5 \mathrm{~nm}$ ) on the photocatalyst surface. ${ }^{12}$ Photocatalytic oxidation (hydroxylation) of benzene was carried out in a Pyrex reaction cell with internal volume of $15 \mathrm{~mL}$ containing a suspension of the photocatalyst powder $(50 \mathrm{mg})$ in an aerated aqueous benzene solution $\left(2.5 \mathrm{mmol} \mathrm{L}{ }^{-1}\right.$, $7.5 \mathrm{~mL}$ ) with continuous stirring using a magnetic stirrer. The reaction temperature was kept at $279 \mathrm{~K}$ by circulating cooling water around the cell. Sample aliquots were withdrawn from the reactor cell after each irradiation and filtered through a PVDF filter to remove photocatalyst particles. Quantitative analysis of solution was carried out using a high performance liquid chromatograph (Shimadzu, LC-10AT VP) equipped with a C-18 column (Shodex, ODP2 HP4E) and a photodiodearray detector. Generation of carbon dioxide $\left(\mathrm{CO}_{2}\right)$ in the gas phase was analyzed by gas chromatography.

Figure 1 shows the time-course curves of photocatalytic reactions over $\mathrm{Pt} / \mathrm{WO}_{3}-\mathrm{K}$ and $\mathrm{Pt} / \mathrm{TiO}_{2}-\mathrm{P} 25$ in aqueous solutions of benzene $\left(2.5 \mathrm{mmol} \mathrm{L}{ }^{-1}, 7.5 \mathrm{~mL}\right)$ in the presence of molecular oxygen under the full arc irradiation with a 300W xenon lamp $(\lambda>300 \mathrm{~nm})$.

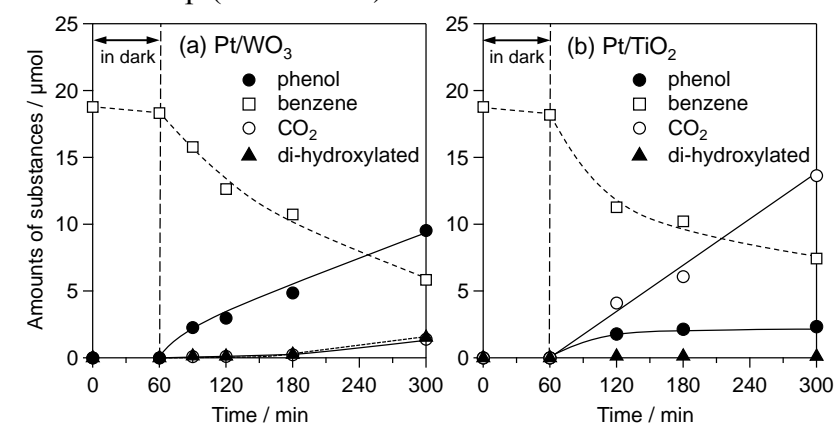

Figure 1. Time courses of photocatalytic oxidation of benzene over (a) $\mathrm{Pt} / \mathrm{WO}_{3}-\mathrm{K}$ and (b) $\mathrm{Pt} / \mathrm{TiO}_{2}-\mathrm{P} 25$ in aerated aqueous solutions of benzene $(18.8 \mu \mathrm{mol})$ under ultraviolet and visible light $(300<\lambda<500 \mathrm{nn})$. 
Table 1. Photocatalytic oxidation of benzene by $\mathrm{WO}_{3}$ and $\mathrm{TiO}_{2}$ photocatalysts $^{\mathrm{a}}$

\begin{tabular}{|c|c|c|c|c|c|c|c|c|c|c|}
\hline \multirow[b]{2}{*}{ Entry } & \multirow[b]{2}{*}{ Sample } & \multirow{2}{*}{\multicolumn{2}{|c|}{ Conditions }} & \multirow[b]{2}{*}{$\begin{array}{l}\text { Conversion } \\
(\%)^{(b)} \\
\text { (Irradiation } \\
\text { time) }\end{array}$} & \multicolumn{5}{|c|}{ Selectivity $(\%)^{(c)}$} & \multirow{2}{*}{$\begin{array}{l}\text { Amount of } \\
\mathrm{CO}_{2} / \mathrm{mol}\end{array}$} \\
\hline & & & & & & & & & & \\
\hline \multirow{2}{*}{1} & \multirow{2}{*}{$\mathrm{Pt} / \mathrm{WO}_{3}-\mathrm{K}$} & $\lambda>300$ & $\mathrm{O}_{2}$ & $22.2(60)$ & 79.3 & 1.9 & 0 & 1.2 & 4.0 & $<0.1$ \\
\hline & & $\lambda>300$ & $\mathrm{O}_{2}$ & $68.9(240)$ & 73.7 & 2.3 & 0.7 & 0 & 8.8 & 1.4 \\
\hline \multirow{2}{*}{2} & \multirow{2}{*}{$\mathrm{Pt} / \mathrm{WO}_{3}-\mathrm{K}$} & $\lambda>400$ & $\mathrm{O}_{2}$ & $26.6(60)$ & 83.8 & 1.4 & 0 & 1.2 & 2.8 & $<0.1$ \\
\hline & & $\lambda>400$ & $\mathrm{O}_{2}$ & $52.5(240)$ & 75.1 & 1.4 & 0 & 2.9 & 1.2 & 0.6 \\
\hline 3 & $\mathrm{WO}_{3}-\mathrm{K}$ & $\lambda>300$ & $\mathrm{O}_{2}$ & $16.4(240)$ & 84.6 & 1.6 & 0 & 3.3 & 1.1 & $<0.1$ \\
\hline 4 & $\mathrm{Pt} / \mathrm{WO}_{3}-\mathrm{Y}$ & $\lambda>300$ & $\mathrm{O}_{2}$ & $40.6(60)$ & 58.8 & 1.2 & 0 & 1.3 & 1.1 & $<0.1$ \\
\hline 5 & $\mathrm{Pt} / \mathrm{WO}_{3}-\mathrm{S}$ & $\lambda>300$ & $\mathrm{O}_{2}$ & $32.4(60)$ & 48.7 & 1.2 & 0 & 2.0 & 1.2 & 0.6 \\
\hline \multirow{2}{*}{6} & \multirow{2}{*}{$\mathrm{Pt} / \mathrm{TiO}_{2}-\mathrm{P} 25$} & $\lambda>300$ & $\mathrm{O}_{2}$ & $38.0(60)$ & 25.9 & 0 & 0 & 0.6 & 1.1 & 4.1 \\
\hline & & $\lambda>300$ & $\mathrm{O}_{2}$ & $59.1(240)$ & 21.8 & 0 & $<0.1$ & 0.8 & 0.1 & 13.6 \\
\hline \multirow{2}{*}{7} & \multirow{2}{*}{$\mathrm{Pt} / \mathrm{TiO}_{2}-\mathrm{P} 25$} & $\lambda>300$ & $\mathrm{Ar}$ & $13.3(60)$ & 60.8 & 0 & 0 & 0.9 & 0 & 0.4 \\
\hline & & $\lambda>300$ & $\mathrm{Ar}$ & $33.8(240)$ & 34.0 & 0 & 0.1 & 0.7 & 0 & 0.3 \\
\hline 8 & $\mathrm{TiO}_{2}-\mathrm{P} 25$ & $\lambda>300$ & $\mathrm{O}_{2}$ & $82.5(240)$ & 20.6 & $<0.1$ & 0 & 0.8 & 0.1 & 13.4 \\
\hline 9 & $\mathrm{Pt} / \mathrm{TiO}_{2}-\mathrm{M}$ & $\lambda>300$ & $\mathrm{O}_{2}$ & $43.0(60)$ & 31.0 & 2.8 & 0 & 1.9 & 0 & 0.8 \\
\hline 10 & $\mathrm{Pt} / \mathrm{TiO}_{2}-\mathrm{J}$ & $\lambda>300$ & $\mathrm{O}_{2}$ & $48.9(60)$ & 26.5 & 0 & 1.3 & 0.1 & 0 & 1.2 \\
\hline \multirow[b]{2}{*}{11} & \multirow[b]{2}{*}{$\mathrm{Pt} / \mathrm{TiO}_{2}-\mathrm{J}$} & $\lambda>300$ & $\mathrm{Ar}$ & $11.5(15)$ & 63.0 & 0 & 0 & 0.7 & 0 & $<0.1$ \\
\hline & & $\lambda>300$ & $\mathrm{Ar}$ & $38.6(60)$ & 35.4 & 0 & 0.2 & 0.7 & 0 & 0.1 \\
\hline
\end{tabular}

(a) Initial concentration of benzene : $2.5 \mathrm{mmol} \mathrm{L}^{-1}$, Solvent : $\mathrm{H}_{2} \mathrm{O} 7.5 \mathrm{~mL}$, Light source : $300 \mathrm{~W}$ Xe lamp, (b) Conversion : $\left(\mathrm{C}_{\text {benzene, } 0}-\mathrm{C}_{\text {benzene, },}\right) / \mathrm{C}_{\text {benzene, } 0} \times 10^{2}$,

(c) Selectivity : $\mathrm{C}_{\text {products, } t},\left(\mathrm{C}_{\text {benzene, } 0}-\mathrm{C}_{\text {benzene, }, t}\right) \times 10^{2}$

As seen in Fig. 1-a, phenol was produced with almost constant rate over $\mathrm{Pt} / \mathrm{WO}_{3}-\mathrm{K}$ photocatalyst after $30 \mathrm{~min}$ of irradiation along with the consumption of benzene. Small amounts of di-hydroxylated benzenes such as catechol or hydroquinone were also produced (see entry 1 in Table 1 ). Although appreciable generation of $\mathrm{CO}_{2}$ (ca. $1.4 \mu \mathrm{mol}$ ) was observed in gas phase after the prolonged irradiation (240 $\min$ ), the amount of $\mathrm{CO}_{2}$ produce was much smaller than that of phenol (ca. $9.5 \mu \mathrm{mol})$. The production of phenol was also observed over the $\mathrm{Pt} / \mathrm{TiO}_{2}-\mathrm{P} 25$ as seen in Fig. 1-b, while the phenol production was saturated within 60 min of irradiation accompanied by significant increase of $\mathrm{CO}_{2}$ generation, suggesting that the once-produced phenol was subsequently oxidized over the photocatalyst. ${ }^{13-17}$

As summarized in Table 1, photocatalytic reaction over $\mathrm{Pt} / \mathrm{WO}_{3}-\mathrm{K}$ resulted in highly selective phenol production with $79 \%$ of selectivity at $22 \%$ of benzene conversion in initial period (30 min). Even after the long time irradiation of 240 min, a high selectivity of $74 \%$ was still obtained at $69 \%$ of benzene conversion (entry 1) along with the production of catechol (2.3\%), resorcinol $(0.7 \%)$ and p-benzoquinone $(8.8 \%)$, resulting in $85.5 \%$ of selectivity for hydroxylated benzene or quinone products from benzene. It should be noted here that the products without aromatic ring could not be quantified in the present study. Therefore, other unidentified parts (ca. 14\%) are certainly corresponding to the various intermediate compounds produced through the cleavage of aromatic ring, as well as to the final oxidative product $\mathrm{CO}_{2}$. Visible light irradiation $(\lambda>400 \mathrm{~nm})$ afforded better phenol selectivity (entries 2 ) on $\mathrm{Pt} / \mathrm{WO}_{3}-\mathrm{K}$ photocatalyst compared to the case of full arc irradiation (entries 1). Other $\mathrm{Pt} / \mathrm{WO}_{3}$ samples also showed relatively high selectivity for phenol production above $48 \%$ (entries 4 and 5). On the other hand, all the $\mathrm{Pt} / \mathrm{TiO}_{2}$ photocatalysts showed much lower selectivity for phenol production below $31 \%$ in the presence of $\mathrm{O}_{2}$ even at low conversions of benzene (entries 6, 9 and 10). In all cases $\mathrm{H}_{2}$ production was negligible, indicating that almost all of the photoexcited electrons were consumed to reduce molecular $\mathrm{O}_{2}$, not water $\left(\right.$ or $\mathrm{H}^{+}$). It should be noted that the $\mathrm{Pt} / \mathrm{WO}_{3}-\mathrm{K}$ and the $\mathrm{Pt} / \mathrm{TiO}_{2}-\mathrm{M}$, which have similar surface

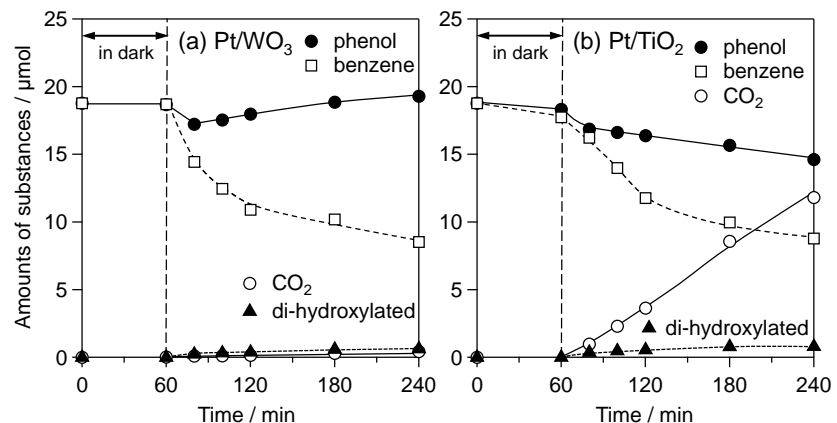

Figure 2. Time courses of photocatalytic reaction over (a) $\mathrm{Pt} / \mathrm{WO}_{3}-\mathrm{K}$ and (b) $\mathrm{Pt} / \mathrm{TiO}_{2}-\mathrm{P} 25$ in aerated aqueous solutions containing both benzene $(18.8 \mu \mathrm{mol})$ and phenol $(18.8 \mu \mathrm{mol})$ under ultraviolet and visible light $(300<\lambda<500 \mathrm{~nm})$.

areas $\left(\right.$ ca. $\left.10 \mathrm{~m}^{2} \cdot \mathrm{g}^{-1}\right)$, showed apparently different reactivity. Thus, the factor dominating the reactivity undoubtedly rests on the difference in the composition $\left(\mathrm{WO}_{3}\right.$ or $\left.\mathrm{TiO}_{2}\right)$ but not on the surface areas. As expected by the photoabsorption property of $\mathrm{TiO}_{2}$, visible light irradiation did not yield any appreciable products over $\mathrm{Pt} / \mathrm{TiO}_{2}$ photocatalysts.

These results suggested that the rates of subsequent oxidations of phenol on $\mathrm{Pt} / \mathrm{WO}_{3}$ photocatalysts are much lower than those on $\mathrm{Pt} / \mathrm{TiO}_{2}$ photocatalysts, enabling the high selectivity of phenol to be obtained in $\mathrm{Pt} / \mathrm{WO}_{3}$ photocatalyst systems. To examine this, the photocatalytic reactions were carried out in the co-existence of benzene and phenol. As shown in Fig. 2-a, the amount of phenol was first decreased and then increased with steady rate over $\mathrm{Pt} / \mathrm{WO}_{3}-\mathrm{K}$ photocatalyst along with decrease of benzene. This indicates that the rate of phenol production on $\mathrm{Pt} / \mathrm{WO}_{3}-\mathrm{K}$ is higher than that of subsequent oxidation of phenol, possibly due to the preferential reaction of benzene over phenol on $\mathrm{Pt} / \mathrm{WO}_{3}-\mathrm{K}$ photocatalyst. On the other hand, both benzene and phenol decreased on the $\mathrm{Pt} / \mathrm{TiO}_{2}-\mathrm{P} 25$ photocatalyst, while benzene decreased much faster than phenol. The $\mathrm{CO}_{2}$ generation on $\mathrm{Pt} / \mathrm{TiO}_{2}-\mathrm{P} 25$ was observed from the beginning of the photoirradiation with much higher rate compared to that of di-hydroxylated products, indicating that both the phenol and di-hydroxylated products are readily oxidized with cleavage of the aromatic ring producing various oxidized intermediates and $\mathrm{CO}_{2}$. The faster decrease of benzene suggests another possible reaction pathway on $\mathrm{Pt} / \mathrm{TiO}_{2}-\mathrm{P} 25$; benzene molecules are directly oxidized into $\mathrm{CO}_{2}$ without forming any hydroxylated benzenes. When the photocatalytic oxidation of benzene was carried out in the absence of water, i.e., in dehydrated acetonitrile, no hydroxylated product was obtained on $\mathrm{Pt} / \mathrm{WO}_{3}-\mathrm{K}$ nor $\mathrm{Pt} / \mathrm{TiO}_{2}-\mathrm{P} 25$ photocatalysts, indicating that the hydroxyl groups were originated from water molecules. It has been reported that hydroxyl radicals $(\bullet \mathrm{OH})$ are produced through the reaction of photogenerated holes with water molecules adsorbed on the photocatalyst surface: ${ }^{18-19}$

$$
\begin{gathered}
\text { photocatalyst }+\mathrm{h} v \rightarrow \mathrm{e}^{-}+\mathrm{h}^{+} \\
\mathrm{h}^{+}+\mathrm{H}_{2} \mathrm{O} \rightarrow \mathrm{H}^{+}+\bullet \mathrm{OH}
\end{gathered}
$$

The hydroxyl radical certainly reacts with benzene (or phenol) to generate hydroxylated benzene radical, which are then oxidized by a hole on a photocatalyst surface and deprotonated producing phenol (or di-hydroxylated benzenes), as shown below. ${ }^{20}$

$$
\square+\cdot \mathrm{OH} \rightarrow \overbrace{}^{\mathrm{OH}}
$$




$$
\underbrace{\mathrm{OH}}+\mathrm{h}^{+} \longrightarrow
$$

Interestingly, stoichiometric amount of $\mathrm{CO}_{2}$ to the decreased benzene was found to generate from benzene-acetonitrile solution with a relatively high rate when $\mathrm{Pt} / \mathrm{TiO}_{2}-\mathrm{P} 25$ photocatalyst was irradiated in the presence of $\mathrm{O}_{2}$, while no $\mathrm{CO}_{2}$ gas was generated on $\mathrm{Pt} / \mathrm{WO}_{3}-\mathrm{K}$ in a same time scale of irradiation $(\sim 120 \mathrm{~min})$. This result indicates the presence of reaction pathway of direct oxidation of benzene on $\mathrm{Pt} / \mathrm{TiO}_{2-}$ P25 surface by photogenerated holes into $\mathrm{CO}_{2}$ without forming any hydroxylated benzenes. It appears that the direct oxidation of benzene occurs preferentially on $\mathrm{Pt} / \mathrm{TiO}_{2}-\mathrm{P} 25$ photocatalyst even in aqueous solution, resulting in the significant generation of $\mathrm{CO}_{2}$ from the initial period (see Fig. 1-b). On the other hand, the holes generated on $\mathrm{Pt} / \mathrm{WO}_{3}$ photocatalysts possibly react with water preferentially over benzene, resulting in the preferential generation of $\bullet \mathrm{OH}$ that can produce phenol from benzene without cleavage of aromatic ring. The different participation of molecular oxygen $\left(\mathrm{O}_{2}\right)$ to the reactions seems to be another reason for the different reactivity between $\mathrm{WO}_{3}$ and $\mathrm{TiO}_{2}$ photocatalysts. It is well known that bare $\mathrm{WO}_{3}$ is not an efficient photocatalyst for oxidation of organic compounds in the presence of $\mathrm{O}_{2}$ because the conduction band $(\mathrm{CB})$ bottom (ca. $+0.5 \mathrm{~V}_{\mathrm{NHE}}$ ) potential is insufficient for the reduction of $\mathrm{O}_{2}\left[\mathrm{E}^{0}\left(\mathrm{O}_{2} / \mathrm{O}_{2}{ }^{-} \bullet\right)=\right.$ $-0.33 \mathrm{~V}_{\mathrm{NHE}}$ and $\left.\mathrm{E}^{0}\left(\mathrm{O}_{2} / \mathrm{HO}_{2} \bullet\right)=-0.05 \mathrm{~V}_{\mathrm{NHE}}\right]$ in a one-electron process. The incapability of $\mathrm{O}_{2}$ to scavenge the electrons in $\mathrm{CB}$ of $\mathrm{WO}_{3}$ results in the fast recombination and the lower photocatalytic activity. Indeed, bare $\mathrm{WO}_{3}$ photocatalyst showed much lower conversion for the photocatalytic reaction with benzene (entry 3 ) compared to that on $\mathrm{Pt} / \mathrm{WO}_{3}$, while the selectivity for phenol production was high. We have recently demonstrated that Pt-loaded $\mathrm{WO}_{3}$ exhibits high photocatalytic activity for decomposition of various aliphatic compounds due to the promotion of multi-electron reduction of $\mathrm{O}_{2}$ on the Pt cocatalysts. ${ }^{12}$ It was also confirmed that the reduction product of $\mathrm{O}_{2}$ was mainly hydrogen peroxide $\left(\mathrm{H}_{2} \mathrm{O}_{2}\right)$ generated via two-electron process $\left[\mathrm{E}^{0}\left(\mathrm{O}_{2} / \mathrm{H}_{2} \mathrm{O}_{2}\right)=+0.55\right.$ $\left.\mathrm{V}_{\mathrm{NHE}}\right]$. Negligible reaction occurred by the simple mixture of benzene and $\mathrm{H}_{2} \mathrm{O}_{2}$ in water, indicating that the $\mathrm{H}_{2} \mathrm{O}_{2}$ itself cannot participate to the oxidation (hydroxylation) of benzene. On the other hand, $\mathrm{TiO}_{2}$ photocatalysts possess sufficiently negative $\mathrm{CB}$ bottom for one-electron reduction of $\mathrm{O}_{2}$. Therefore $\mathrm{TiO}_{2}$ can reduce $\mathrm{O}_{2}$ even without $\mathrm{Pt}$ cocatalyst resulting in efficient oxidation of organic compounds by holes. Interestingly, bare $\mathrm{TiO}_{2}-\mathrm{P} 25$ showed higher rate for benzene oxidation than $\mathrm{Pt} / \mathrm{TiO}_{2}-\mathrm{P} 25$ (see entries 6 and 8), implying that most of the photoexcited electrons were consumed on the $\mathrm{TiO}_{2}$ surface, not on $\mathrm{Pt}$, via single electron processes producing radical species of $\mathrm{O}_{2}$ (e.g., $\mathrm{O}_{2}^{-} \bullet$ or $\mathrm{HO}_{2} \bullet$ ). It has been suggested that the presence of $\mathrm{O}_{2}$ enhances the oxidation of organic compounds in some $\mathrm{TiO}_{2}$ photocatalysis systems via radical chain reaction mechanism. ${ }^{21}$ It therefore appears that such radical species of $\mathrm{O}_{2}$ also enhances the oxidative decomposition, especially the cleavage of aromatic ring, of benzene, resulting in low selectivity of phenols. Indeed, the reaction of $\mathrm{Pt} / \mathrm{TiO}_{2}-\mathrm{P} 25$ in the absence of $\mathrm{O}_{2}$ (entry 7), in which an appreciable amount of $\mathrm{H}_{2}$ was produced during the photoirradiation, showed much higher selectivity for phenol $(60.7 \%$ at $13.3 \%$ of conversion) than that in the presence of $\mathrm{O}_{2}$, while the reaction rate was lowered considerably due to the lower capability of $\mathrm{H}_{2} \mathrm{O}$ (or $\mathrm{H}^{+}$) to capture the photoexcited electrons compared to that of $\mathrm{O}_{2}$. These results strongly suggest that the different behavior of $\mathrm{O}_{2}$ in the reactions is one of the reasons for the different reactivity in benzene oxidation between $\mathrm{WO}_{3}$ and $\mathrm{TiO}_{2}$ photocatalysts. However, the selectivity for phenol drastically decreased in prolonged reactions on the $\mathrm{Pt} / \mathrm{TiO}_{2}$ photocatalyst even in the absence of $\mathrm{O}_{2}$ (entries 7,11 ), indicating that the different behavior of $\mathrm{O}_{2}$ is not the sole reason for the different reactivity between $\mathrm{WO}_{3}$ and $\mathrm{TiO}_{2}$ photocatalysts. As suggested above, the different reactivity of holes toward benzene and water certainly may contribute to the different reactivity. Further investigation is now under way to clarify the reaction mechanism for hydroxylation of benzene on $\mathrm{Pt} / \mathrm{WO}_{3}$ photocatalysts.

In conclusion, it was first demonstrated that $\mathrm{Pt} / \mathrm{WO}_{3}$ photocatalysts showed activity for direct production of phenol from benzene using water and $\mathrm{O}_{2}$ as reactants under UV or visible light. The selectivity for phenol on $\mathrm{Pt} / \mathrm{WO}_{3}$ photocatalysts was much higher than those on $\mathrm{Pt} / \mathrm{TiO}_{2}$ (or $\mathrm{TiO}_{2}$ ) photocatalysts. These results demonstrate the potential of $\mathrm{Pt} / \mathrm{WO}_{3}$ photocatalysts for highly selective organic synthesis with environmentally benign oxidants such as water and/or $\mathrm{O}_{2}$ using abundant visible light included in solar radiation.

This study was supported by the 2007 Industrial Technology Research Grant Program from the New Energy and Industrial Technology Development Organization (NEDO) of Japan.

\section{References and Notes}

1 Robert J. Schmidt, Appl. Catal. A 2005, 280, 89

2 S. Niwa, M. Eswaramoorthy, J. Nair, A. Raj, N. Itoh, H. Shoji, T. Namba, F. Mizukami, Science 2002, 295, 105.

3 L.V. Pirutko, V.S. Chernyavsky, A.K. Uriarte, G.I. Panov, Appl. Catal. A 2002, 227, 143

4 D. Bianchi, L. Balducci, R. Bortolo, R. D’Aloisio, M. Ricci, G. Spano, R. Tassinari, C. Tonini, R. Ungarelli, Adv. Synth. Catal. 2007, 349, 979.

$5 \quad$ M. Fujihira, Y. Satoh, T. Osa, Nature 1981, 293.

6 Y. Shimamura, H. Misawa, T. Oguchi, T. Kannno, H. Sakuragi, K. Tokumaru, Chem. Lett. 1983, 1691.

7 K. Shimizu, H. Akahane, T. Kodama, Y. Kitayama, Appl. Catal. A 2002, 225, 185.

8 H. Park, W. Choi, Catal. Today 2005, 101, 291.

9 G. Zhang, J. Yi, J. Shim, J. Lee, W. Choi, Appl. Catal. B 2011, 102 132.

10 T. D. Bui, A. Kimura, S. Ikeda, M. Matsumura, Appl. Catal. B 2010, 94, 186.

11 H. Yoshida, H. Yuzawa, M. Aoki, K. Otake, H. Itoh, T. Hattori, Chem. Commun. 2008, 4634.

12 R. Abe, H. Takami, N. Murakami, B. Ohtani, J. Am. Chem. Soc. 2008, 130, 7780 .

13 K. Okamoto, Y. Yamamoto, H. Tanaka, M. Tanaka, A. Itaya, Bull. Chem. Soc. Jpn. 1985, 58, 2015.

14 C. A. Emilio, M. I. Litter, C. Colbeau-Justin, Langmuir 2006, 22, 3606.

15 A. Aaron Ortiz-Gomez, B. Serrano-Rosales, M. Salaices, H. D. Lasa, Ind. Eng. Chem. Res. 2007, 46, 7394.

16 M. Kepczynski, A. Czonsyka, M. Nowakowska. J. Photochem. Photobiol. A Chem. 2007, 185, 198.

17 M. Salaices, B. Serrano, H. I. Lasa, Chem. Eng. Sci. 2004, 59, 3.

18 J. Kim, C. W. Lee, W. Choi, Environ. Sci. Technol. 2010, 44, 6849.

19 Y. Nosaka, S. Komori, K. Yawata, T. Hirakawa, A. Y. Nosaka, Phys. Chem. Chem. Phys. 2003, 5, 4731 .

20 C. Walling, Acc. Chem. Rev. 1975, 125.

21 B. Ohtani, Y. Nohara, R. Abe, Electrochem. 2008, 76, 147. 


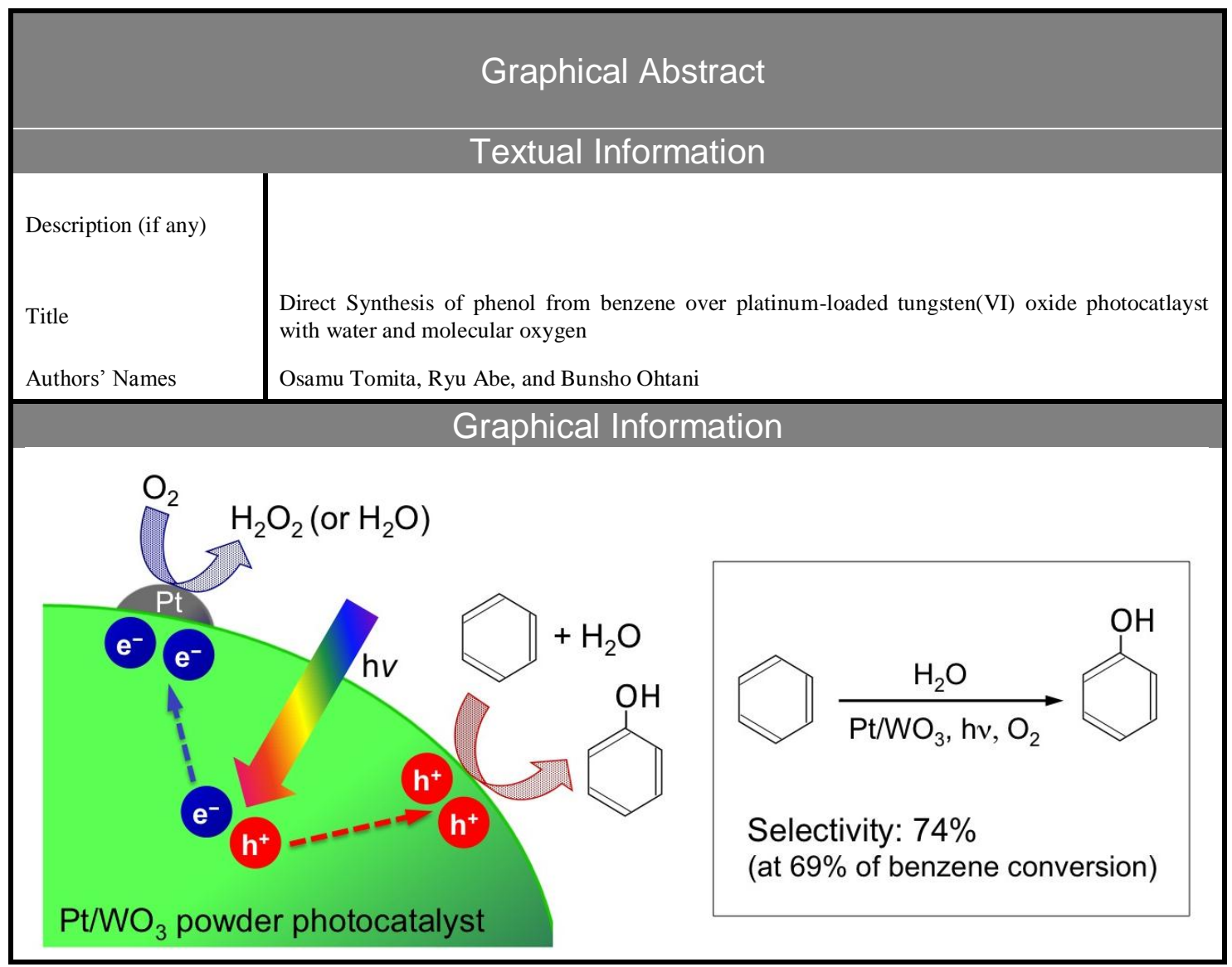

